\title{
Dicţionar explicativ poliglot de termeni din domeniul educaţiei: (română, engleză, germană, franceză). Book review
}

Mariana Cernicova-Buca•

By

\section{Simona ŞIMON, Anca DEJICA-CARŢIŞ, Claudia E. STOIAN, Andrea KRISTON - Timişoara: Editura Politehnica, 2018}

ISBN: 978-606-35-0251-4, 230 pages

Multilingualism is the heart of Europe. At least, this is one of the prerequisites of building a coherent, borderless

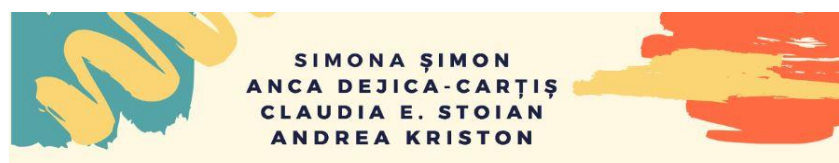
space, in which everyone would feel "at home" while traveling, working, training, learning or living anywhere

DICTIIONAR EXPLICATIV POLIGLOT DE TERMENIDIN DOMENIUL EDUCATI I I from Cape Greco (Cyprus) to Cabo da Roca (Portugal), from Nuorgam (Lapland, Finland) to Punta de Tarifa (Straits of Gibraltar, Spain). It is ambitiously defined by the European

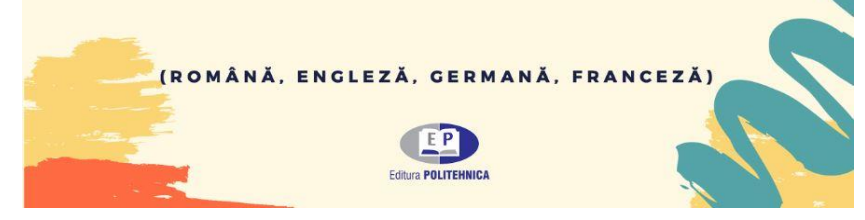
Union as one of the eight key competences for lifelong learning (Council Recommendation 2019/C 189/03) and strongly recommended as the Northern Star of education for every literate European, who should master from an early age at least two foreign languages other than one's native one. "Learning languages enables people to both discover foreign cultures and to broaden their perspectives" - states the already quoted Council Recommendation, even while various studies and news reports deplore the low achievement of the tri- or multi-lingual skills of the Europeans, almost two decades after the goal of tri-lingualism was set (Harris, 2016).

In such a context, the intellectual journey proposed by four academics at Politehnica University Timisoara (Romania), Simona Şimon, Anca Dejica-Carţiş, Claudia E. Stoian and Andrea Kriston is both bold and tempting. Their proposal is to explore the field of education itself, from the point of view of the terms most employed in reference to educational and/or academic life, in Romanian, English, French and German. The choice and order of languages mirror the Romanian educational realities and practice. According to the results of the European Commission study for 2017 "Key Data on Teaching Languages at School in Europe - 2017 Edition. Eurydice Report" the most taught foreign

\footnotetext{
- Assoc. prof. PhD, Department of Communication and Foreign Languages, Politehnica University Timisoara, Romania, e-mail: mariana.cernicova@upt.ro
} 
languages in Romania are, in order of frequency: English, followed by French and German, respectively. These are also the languages of international circulation recommended for the publication of the results of scientific research, providing authors with global impact exposure, recognition, and participation in the global scientific dialogue. Also, these are the most frequently used languages for academic mobilities, and a correct and standardized transcript of educational documents is vital for ensuring that the experiences accumulated by learners and/or teachers are recognizable in the common European Education Area. The four experienced authors combine their experience of translation-interpretation and of language pedagogy in an auspicious manner, demonstrating a strong ability to select relevant dictionary entries and to navigate on the multilingual environment without losing focus of the set forth objective: to offer a versatile and user-friendly tool for professors, academic administrators, translators, students-on-the move.

The dictionary contains 500 Romanian terms frequently used in the field of education, mainly related to the educational process. Each entry contains the term defined in Romanian, from the perspective of this field, followed by its' equivalents in the three selected international languages. In case the Romanian term has meanings that cannot be rendered by the English, German, and/or French translations, then only the meaning common to all four languages has been defined. The dictionary is organized in three parts: the body of educational terms, with definitions, and translations, annexes, and an alphabetical index of the translations of the Romanian terms. The seven annexes containing the sub-domains of education, the structure of the education system, the governing bodies, teaching and leadership functions in pre-university and university education and the important organizations in the field presented in the paper are valuable for the complex understanding of the area of Romanian and European education in the international context. Particularly useful is the alphabetical trilingual index (containing English, German and French terms translated from the Romanian entry), which increases the user's ability to identify the terms that are required for writing, proofreading, or translating a paper on education. The bibliography consulted for the extraction of terms is consistent and relevant, and the coherence of the work and the novelty of the proposed structure draw attention to this valuable contribution to the development of lexicographic practice.

Polyglot or multilingual dictionaries are a tradition for the Romanian-speaking area, dating from the 17th century (M. Seche, 1966). What differs, in time, is the choice of languages. Latin, Slavonic and/or Greek make room for English as the new Lingua franca of our days (M. Mocanu, 2016). While language is the most valued national phenomenon and an intrinsic part of national identity, mastering terms of a certain profession is considered the distinctive feature of an outstanding expert. However, globalization and internationalization not only of the economy but also of the education place additional pressure on the professional: to convey meaning and well-phrased content in languages other than one's native tongue. The reviewed dictionary, Dicționar explicativ poliglot de 
termeni din domeniul educației (română, engleză, germană, franceză) is, in our opinion, a reference tool adequate for pupils, students, teaching, administrative and management staff, translators and interpreters working in the field of education or living its polyphonic realities.

Further work most probably will include an increased number of terms, in a next, revised, and augmented edition. It can prove useful for the compilers of this oeuvre to consult with the team of translators of the European Commission's Executive Agency for Education, Audiovisual and Culture to identify new areas to be covered in the area of information on the evolution of educational structures, to add terms specific for digital pedagogy and online or blended learning. However, these final remarks do not diminish the merits of the book. It is our belief that the polyglot dictionary will greatly contribute to the education and development of self-awareness of its users. Therefore, we urge users to rejoice in it with the same vitality in which it has been compiled and to discover the windows into the international perspective on education opened by this volume.

\section{References}

COUNCIL RECOMMENDATION on a comprehensive approach to the teaching and learning of languages (2019/C 189/03), available on https://ec.europa.eu/education/education-in-the-eu/councilrecommendation-improving-teaching-and-learning-languages en

Harris, C. (2016). Polyglot or 'polynot': a look at language skills across the EU last updated: 04/02/2016, available on https://www.euronews.com/2016/02/04/polyglot-or-polynot-a-look-at-language-skillsacross-the-eu

Baïdak, N., Balcon, M.-P., Motiejunaite, A. (2017). Key Data on Teaching Languages at School in Europe. 2017 Edition. Eurydice Report, Luxembourg: Publications Office of the European Union, http://dx.doi.org/10.2797/62028

Seche, M. (2016). Schiţă de istorie a lexicografiei române, vol. I. De la origini pînă la 1880, București, Editura ştiinţifică, 192 p.

Mocanu, M. (2016). Particular Features of the First Romanian Multilingual Dictionaries, World Academy of Science, Engineering and Technology International Journal of Cognitive and Language Sciences, Vol:10, No:4, pp. 1143- 1148. 